\title{
The Role of Bronchoscopy in Childhood Foreign Body Aspirations: A 3-year Experience
}

\author{
Çocukluk Çağı Yabancı Cisim Aspirasyonlarında Bronkoskopinin Rolü: 3 Yıllık Deneyim
}

\author{
(D) Ömer Katı ${ }^{1}$, (D) Yaşar Kandur2, (D) Şükrü Güngör³, (D) Tahir Dalkıran4 \\ ${ }^{1}$ Necip Fazıl City Hospital, Clinic of Pediatric Surgery, Kahramanmaraş, Turkey \\ ${ }^{2}$ Necip Fazıl City Hospital, Clinic of Pediatric Nephrology, Kahramanmaraş, Turkey \\ ${ }^{3}$ Necip Fazıl City Hospital, Clinic of Pediatric Gastroenterology, Kahramanmaraş, Turkey \\ ${ }^{4}$ Necip Fazıl City Hospital, Clinic of Pediatric Intensive Care, Kahramanmaraş, Turkey
}

\section{Abstract}

Introduction: The purpose of our retrospective study was to define the clinical and radiological features of patients with aspirated foreign bodies, characterize the incidence of foreign body aspiration (FBA) and to compare the results of early and late bronchoscopy.

Methods: We reviewed the medical records of patients who were admitted to the pediatric emergency department of our center due to FBA between 2016 and 2018.

Results: Forty-four patients (M/F 30/14) aged 38.7 \pm 44.1 months (mean \pm standard deviation, range: 5-191) were enrolled in this study. The most common symptoms were cough (42/44) and wheezing (20/44). No foreign body was detected in eight patients (18\%). Regarding the types of foreign bodies, an organic material was observed in 27 (61.4\%) patients with FBA, and a nonorganic material was observed in $9(20.5 \%)$ patients. The mean age of patients with organic FBA was significantly lower than that of patients with non-organic FBA (26 \pm 18 vs. $93 \pm 67$ months, $p=0.005$ ).

Conclusion: Bronchoscopy is an efficient diagnostic tool for patients with suspected FBA because it is associated with low complication risk and reduces the risks of delayed FBA diagnosis and treatment.

Keywords: Foreign body aspiration, bronchoscopy, child

\section{Öz}

Giriş: Bu geriye dönük çalışmanın amacı, yabancı cisim aspirasyonu (YCA) insidansını değerlendirmek, aspire edilen yabancı cisimlerin klinik, radyolojik özelliklerini tanımlamak, erken ve geç bronkoskopi sonuçlarını karşılaştırmaktır.

Yöntemler: 2016-2018 yılları arasında merkezimizin çocuk acil servisine YCA ile başvuran hastaların tıbbi kayıtları geriye dönük olarak incelendi. Çalışmaya dahil edilen tüm hastalara rijit bronkoskopi işlemi uygulandı.

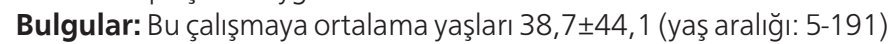
ay olan 44 hasta (E/K 30/14) dahil edildi. En sık görülen semptomlar öksürük (42/44) ve hırıltı (20/44) idi. Sekiz hastada (\%18) yabancı cisim saptanmadı. Bronkoskopi ile çıkarılan yabancı cismin türüne bakıldığında, $27(\% 61,4)$ hastada organik özellikte, 9 (\%20,5) hastada ise organik olmayan özellikte materyal saptandı. Organik materyalin bronkoskopi ile çıkarılması, organik olmayanlardan anlamlı olarak daha geç gerçekleşti $(p=0,048)$. Bu sebeple de bu grupta hastanede kalış süresi daha uzundu $(p=0,032)$. Yabancı cisimler, $8(\% 22,2)$ hastada sol ana bronşta, $19(\% 52,8)$ hastada sağ ana bronş, $2(\% 5,5)$ hastada sağ distal bronş ve $1(\% 2,8)$ hastada sol distal bronşlarda yerleşikti. Hiçbir hastada ölüm olayı gerçekleşmedi. Tüm hastalar bronkoskopi komplikasyonu olmadan taburcu edildi.

Sonuç: Bronkoskopi, YCA şüphesi olan hastalar için etkili bir tanı aracıdır. Düşük komplikasyon riskinin yanı sıra ve YCA tanısında gecikmenin doğuracağı akciğer komplikasyonlarını azaltır.

Anahtar Kelimeler: Yabancı cisim aspirasyonu, bronkoskopi, çocuk

\section{Introduction}

Foreign body aspiration (FBA) occurs most frequently in children between 1 and 3 years of age. ${ }^{1}$ Its incidence is estimated to be $29.9 / 100.000$ persons. $^{2}$ A delay in diagnosis and management can result in devastating consequences including respiratory compromise, failure, and even death. ${ }^{3}$ It occurs in young children due to a lack of proper neuromuscular coordination of the throat, absence of molar 
teeth, poor swallowing of food, their tendency to put objects in the mouth, playing with objects in the mouth, and talking, crying, or moving while eating. ${ }^{4}$ Early symptoms are cough, difficulty in breathing and vomiting; without treatment, obstructive emphysema, atelectasis, lung abscess, empyema, bronchiectasis, pneumothorax, recurrent infections, haemoptysis, and bronchial asthma can also arise. ${ }^{5}$ Peanuts, seeds, food particles, hardware, and pieces of toys are commonly aspirated foreign bodies. ${ }^{6}$ Taking a detailed medical history, performing appropriate physical examinations, and imaging are the first steps for the diagnosis and management of FBA. The foreign body should be removed as early as possible once this condition is confirmed. In recent years, with the development of respiratory endoscopy techniques, bronchoscopy that allows direct visualization of trachea and bronchi has been widely used and has become the major means of removal of airway foreign body. ${ }^{7,8}$ The purposes of our retrospective study were to define the clinical and radiological features of patients with aspirated foreign bodies, characterize the incidence of FBA and compare the results of early and late bronchoscopy.

\section{Materials and Methods}

We reviewed the medical records of patients who were admitted for FBA to the pediatric emergency department at Necip Fazıl City Hospital between 2015 and 2018. All patients included in the study underwent rigid bronchoscopy. Post-operative follow-up of these patients was performed in the pediatric surgery department. Age, sex, complaints on admission, physical examination findings, radiological findings, anatomical region that the foreign body was removed, time to diagnosis, duration of the procedure, and length of hospital stay after the procedure were recorded. The patients were divided into groups on the basis of different variables; the foreign material extracted (organic or inorganic); time to bronchoscopy (early/late bronchoscopy (<24 hr. vs. >24 hr.), and the anatomical site.

The Ethics Committee of the Ministry of Health approved the study.

\section{Statistical Analysis}

Normality of data distribution was analysed by the Kolmogorov-Smirnov test. Differences between the means of continuous variables in two and three groups were evaluated by using Student's t-test or the Mann-Whitney $U$ test and Kruskal-Wallis or ANOVA test, respectively, where applicable. Differences in proportions were assessed using the chi-square test. Correlations between the study parameters were assessed by Pearson/Spearman's correlation coefficient. Group comparisons were assessed by chi-square or ANOVA tests. A p value of less than 0.05 was considered statistically significant. Statistical Package for Social Science (SPSS) version 16.0 (SPSS, Chicago, IL, USA) was used for all statistical analyses.

\section{Results}

Forty-four patients (M/F 30/14) aged 38.7 \pm 44.1 (mean \pm standard deviation, range: 5-191) months were enrolled in this study. Demographic characteristics, admission symptoms and physical examination findings of the patients are summarized in Table 1. The most common symptoms were cough (42/44) and wheezing (20/44). Regarding the types of foreign bodies, an organic material was observed in 27 (61.4\%) patients and a non organic material in $9(20.5 \%)$ (Table 2). No foreign body detected in eight patients (18\%). The mean age of patients with organic FBA was significantly lower than that of the patients with non-organic FBA $(26 \pm 18$ vs. $93 \pm 67$ months; $p=0.005$ ). All the patients with foreign body of nonorganic origin had cough. The organic material was extracted later than the non-organic ones $(3.8 \pm 4.6$ vs. $1.3 \pm 2.1$ day, $\mathrm{p}=0.048$ ), therefore the duration of hospital stay was longer in this group ( $14.9 \pm 23.5$ vs. $2.6 \pm 3.3$ day, $p=0.032$ ). The number of patients with the auscultation finding of unilaterally diminished breath sounds was significantly greater in cases with organic FBA than those with nonorganic FBA [14 (51.8\%) vs. $1(11.1 \%), p=0.006]$. The foreign body types included seeds in $12(27.3 \%)$ patients, metallic objects in 9 $(20.5 \%)$, and fruit and vegetable pieces in 7 (15.9\%).

Foreign bodies were located in the left main bronchus in 8 (22.2\%) patients, the right main bronchus in 19 (52.8\%), the right distal bronchi in 2 (5.5\%), and in the left distal bronchi in $1(2.8 \%)$ patient. Chest $x$-ray findings most commonly included hyperaeration (52.3\%), a normal appearance (44.4\%), atelectasis $(8.3 \%)$, pleural effusion $(5.5 \%)$, opacity $(13.9 \%)$, and pneumothorax (2.8\%). The percentage of patients with a foreign body in the right side was higher than that in the left

\begin{tabular}{|c|c|}
\hline & $n=44$ \\
\hline Age (month)* & $38.7 \pm 44.1$ \\
\hline Male n (\%) & $30(68)$ \\
\hline Number of patients with cough $n(\%)$ & $42(98)$ \\
\hline Number of patients with wheezing $n(\%)$ & $20(45)$ \\
\hline Number of patients with dyspnea $\mathrm{n}(\%)$ & $16(36)$ \\
\hline Number of patients with cyanosis $n(\%)$ & $4(9)$ \\
\hline Number of patients with a history of FBA $n(\%)$ & $23(52)$ \\
\hline $\begin{array}{l}\text { Number of patients with unilateral decrease in } \\
\text { auscultation respiratory sounds } n(\%)\end{array}$ & $14(32)$ \\
\hline FBA: Foreign body aspiration & \\
\hline
\end{tabular}


side $(71 \%$ vs. $33 \%, p=0.049)$. Patients with a foreign body in left bronchus and branches underwent bronchoscopy (77.8\%) later than those with in the right. All the patients with a foreign body location of right and left bronchus had cough. There was no significant difference in the length of hospital stay between patients with a foreign body in the left and right side $(p=0.219)$. The percentage of patients with organic FBA in the left side was non-significantly higher than that in the right side ( $88.9 \%$ vs. $76.2 \%, p=0.230$ ). The time to bronchoscopy after admission was longer in patients with foreign bodies located in the left bronchus and branches than that in those in the right side and in the carina of trachea $(6.8 \pm 5.8,2.0 \pm 3.0$ and $1.9 \pm 2.2$

\begin{tabular}{|c|c|c|c|c|}
\hline & Nonorganic $n=9$ & Organic $\mathbf{n}=\mathbf{2 7}$ & Total $n=36$ & p \\
\hline Age (month)* & $93 \pm 67$ & $26 \pm 18$ & $38 \pm 44$ & 0.005 \\
\hline Late bronchoscopy n (\%) & $1(11)$ & $13(48)$ & 14 & 0.001 \\
\hline Number of patients with cough n (\%) & $9(100)$ & $26(96.3)$ & $35(97.2)$ & 0.558 \\
\hline Number of patients with cyanosis $n(\%)$ & $4(44.4)$ & 0 & $4(11.1)$ & 0.000 \\
\hline Number of patients with a history of FBA $n(\%)$ & $9(100)$ & $6(22.2)$ & $15(41.7)$ & 0.000 \\
\hline $\begin{array}{l}\text { Number of patients with unilateral decrease in auscultation } \\
\text { respiratory sounds } \mathrm{n}(\%)\end{array}$ & $1(11.1)$ & $14(51.8)$ & $14(38.9)$ & 0.006 \\
\hline Number of patients with PA Lung X-ray Pneumothorax n (\%) & 0 & $1(3.7)$ & $1(2.8)$ & 0.558 \\
\hline Number of patients with PA Lung X-ray Opacity $n(\%)$ & $5(55.6)$ & 0 & $5(13.9)$ & 0.000 \\
\hline Duration of hospitalization (day)* & $2.6 \pm 3.3$ & $14.9 \pm 23.5$ & $10.7 \pm 19.2$ & 0.032 \\
\hline Mean time of bronchoscopy (day)* & $1.3 \pm 2.1$ & $3.8 \pm 4.6$ & $3.1 \pm 4.0$ & 0.048 \\
\hline
\end{tabular}

Table 3. Comparison of patient findings according to the anatomic site foreign body removed by bronchoscopy

\begin{tabular}{|c|c|c|c|c|c|}
\hline & $\begin{array}{l}\text { Carina of } \\
\text { Trachea } \\
n=6\end{array}$ & $\begin{array}{l}\text { Right bronchus } \\
\text { and branches } \\
n=21\end{array}$ & $\begin{array}{l}\text { Left bronchus } \\
\text { and branches } \\
n=9\end{array}$ & Total & $\mathbf{p}$ \\
\hline Patents with organic foreign body $n$ (\%) & $3(50)$ & $16(76.2)$ & $8(88.9)$ & 27 & 0.230 \\
\hline Late bronchoscopy n (\%) & $2(33.3)$ & $5(23.8)$ & $7(77.8)$ & $14(36.1)$ & 0.020 \\
\hline Number of patients with a history of FBA $n(\%)$ & 0 & $15(71)$ & $3(33)$ & 15 & 0.049 \\
\hline Number of patients with cough n (\%) & $5(83.3)$ & $21(100)$ & $9(100)$ & $35(97.2)$ & 0.076 \\
\hline Number of patients with wheezing $n(\%)$ & 0 & $10(47.6)$ & $4(44.4)$ & 14 (38.9) & 0.10 \\
\hline Number of patients with dyspnea n (\%) & $4(66.7)$ & $8(38.1)$ & $4(44.4)$ & $16(44.4)$ & 0.462 \\
\hline Number of patients with cyanosis n (\%) & $2(33.3)$ & $2(9.5)$ & 0 & $4(11.1)$ & 0.124 \\
\hline Number of patients with normal X-ray $n(\%)$ & $3(50)$ & $6(28.6)$ & $1(11.1)$ & $10(27.8)$ & 0.255 \\
\hline Number of patients with hiperaeration $n(\%)$ & $1(16.7)$ & $12(57.1)$ & $3(33.3)$ & $16(44.4)$ & 0.158 \\
\hline Number of patients with atelectasis $n(\%)$ & 0 & 0 & $3(33.3)$ & $3(8.3)$ & 0.007 \\
\hline Number of patients with effusion $n(\%)$ & 0 & 0 & $2(22.2)$ & $2(5.6)$ & 0.042 \\
\hline Number of patients with pneumothorax $n(\%)$ & $1(16.7)$ & 0 & 0 & $1(2.8)$ & 0.076 \\
\hline Number of patients with opacity $n(\%)$ & $1(16.7)$ & $3(14.3)$ & $1(11.1)$ & $5(13.9)$ & 0.951 \\
\hline Duration of hospitalization (day)* & $9.8 \pm 16.6$ & $7.9 \pm 19.0$ & $22.4 \pm 26.2$ & $10.7 \pm 19.2$ & 0.219 \\
\hline Mean time of bronchoscopy (day)* & $1.9 \pm 2.2$ & $2.0 \pm 3.0$ & $6.8 \pm 5.8$ & $3.1 \pm 4.0$ & 0.009 \\
\hline $\begin{array}{l}\text { *All values are presented as the mean } \pm \text { standard deviation } \\
\text { FBA: Foreign body aspiration }\end{array}$ & & & & & \\
\hline
\end{tabular}


days, respectively $p=0.009$ ). The number of patients with wheezing was non-significantly greater in patients with FBA in the right side than those with in the left side and the carina of trachea $(p=0.10)$. Atelectasis and pleural effusion were significantly more common in patients with left-sided foreign bodies than in those with right-sided ones and in the carina of trachea ( $p=0.007$ and $p=0.042$, respectively). The length of hospital stay was longer in cases with FBA of left bronchus and branches than right one and carina of trachea (6.8 85 .8 days, $2.0 \pm 3.0$ days, and $1.9 \pm 2.2$ days, respectively; $\mathrm{p}=0.009$ ) (Table 3). Two patients required repeated bronchoscopy due to fibrin plugs. None of the patients died.

\section{Discussion}

In the present study, we analyzed the data of children suspected of having FBA. It has been demonstrated that FBA under 3 years of age constituted $60-90 \%$ of the all pediatric cases. ${ }^{9-11}$ In our study, 27 patients (75\%) with FBA were less than 3 years of age.

We found a percentage of $88.9 \%$ for organic FBA. This was consistent with the literature reports. ${ }^{9,12}$ A recent study on 115 children reported a corresponding rate of $79 \% .{ }^{13}$ This indicates that organic materials are aspired at higher rates in children less than three years of age. In many studies, the incidence of FBA has been reported to be higher in males than in females, and it has been suggested that they may originate from differences in their activities..$^{14,15}$ In our study, similarly, FBA was twice as many in males.

We found that cough and wheezing were the most common complaints, as other studies have shown that cough occurs in $48-88 \%$ of patients, wheezing in $44-50 \%$, and respiratory distress in $18-22 \% .9,10,16$

Ghafari et al. ${ }^{15}$ showed that in cases of FBA, the most common radiological findings were emphysema (44\%) and atelectasis (16\%). In another study, ${ }^{1}$ it was reported that the most common radiological findings were unilateral emphysema (64\%). In our study, the most common radiological finding was also emphysema (44.4\%). The radiological findings were normal in 10 patients (27.8\%) in our study. This rate was either higher or lower in previous studies.9,17

In our study, 8 (18.2\%) patients had no finding of foreign body on bronchoscopy. Previous studies, 10,13,18,19 have shown similar rates of negative bronchoscopy (10-38\%). However, if tracheobronchial FBA is suspected, it is suggested to be investigated using bronchoscopy because the morbidity resulting from bronchoscopy is less than that due to severe airway obstruction. ${ }^{20}$ Moreover, suspicion and history of FBA lead to a relatively shorter length of hospital stay and duration of bronchoscopy in right sided FBA.
Since the right main bronchus is wider, shorter, and closer to the trachea than the left counterpart, FBA most commonly occurs in the right bronchus. ${ }^{9,10,21}$ On the contrary, there are also studies indicating that there is no difference between the right and left bronchi in terms of aspiration rate. ${ }^{15}$ In our study, we detected foreign bodies mostly in the right bronchi among 21 patients (58.3\%). Because the percentage of patients with a history of FBA was higher in the right side located FBA group than the left sided one, bronchoscopy was performed earlier. Thus, foreign bodies in the right main bronchus and trachea were detected earlier than those in the left main bronchus. Therefore, we found that patients with foreign bodies in the left bronchus and its branches had a longer total and postbronchoscopy hospitalization than those with foreign bodies at other sites, although the difference did not reach statistical significance. We found higher rates of atelectasis and pleural effusion for left-sided foreign bodies.

\section{Study Limitations}

The major limitation of our study is that our data were collected and analyzed retrospectively, which precluded us from controlling the accuracy of the parameters collected such as history taking, physical examination findings, and chest x-ray interpretation.

\section{Conclusion}

We conclude from our study that especially in children younger than three years of age suspected of having FBA, bronchoscopy should be performed as soon as possible. Bronchoscopy is an efficient diagnostic tool for patients with suspected FBA because it is associated with low complication risk and reduces the risks of delayed FBA diagnosis and treatment.

\section{Ethics}

Ethics Committee Approval: The Ethics Committee of the Ministry of Health approved the study.

Informed Consent: Retrospective study.

Peer-review: Externally and internally peer-reviewed.

\section{Authorship Contributions}

Surgical and Medical Practices: Y.K., Ö.K., Ş.G., T.D., Concept: Y.K., Ö.K., Ş.G., Design: Y.K., Ö.K., Ş.G., Data Collection or Processing: Y.K., Analysis or Interpretation: Y.K., Literature Search: Y.K., Writing: Y.K.

Conflict of Interest: No conflict of interest was declared by the authors.

Financial Disclosure: The authors declared that this study received no financial support. 


\section{References}

1. Gregori D, Salerni L, Scarinzi C, Morra B, Berchialla P, et al. ESFBI Study Group. Foreign bodies in the upper airways causing complications and requiring hospitalization in children aged 0-14 years: results from the ESFBI study. Eur Arch Otorhinolaryngol. 2008;265:971-8.

2. Reilly J, Thompson J, MacArthur C, Pransky S, Beste D, et al. Pediatric aerodigestive foreign body injuries are complications related to timeliness of diagnosis. Laryngoscope. 1997;107:17-20.

3. Passali $D$, Lauriello $M$, Bellussi $L$, Passali G, Passali F, et al. Foreign body inhalation in children: an update. Acta Otorhinolaryngol Ital. 2010;30:27-32.

4. Chiu CY, Wong KS, Lai SH, Hsia SH, Wu CT. Factors predicting early diagnosis of foreign body aspiration in children. Pediatr Emerg Care. 2005:21:161-4.

5. Sultan $T A$, van $A s A B$. Review of tracheobronchial foreign body aspiration in the South African paediatric age group. J Thorac Dis. 2016:8:3787-96.

6. Tan HK, Brown K, McGill T, Kenna MA, Lund DP, et al. Airway foreign bodies (FB): a 10-year review. Int J Pediatr Otorhinolaryngol. 2000;56:91-9.

7. Herth FJ, Eberhardt R and Ernst A. The future of bronchoscopy in diagnosing, staging and treatment of lung cancer. Respiration. 2006:73:399-409.

8. Jacobs IN. Bronchoscopy. In: Mattei P. editor. Fundamentals of Pediatric Surgery. New York: Springer, 2011;185-194.

9. Haddadi S, Marzban S, Nemati S, Ranjbar Kiakelayeh S, Parvizi A, et al. Tracheobronchial Foreign-Bodies in Children; A 7 Year Retrospective Study. Iran J Otorhinolaryngol. 2015;27:377-85.

10. Ozsoylu S, Akyıldız B, Dursun A. Foreign Body Aspiration: Our 6 Year Experiences. Bozok Med J. 2017;7:43-6.

11. Farzizadeh $M$, Hashemian $H$, AtrKarRoshan Z. Clinical and radiographic findings of foreign body aspiration in children hospitalized in 17 Shahrivar Hospital, Rasht, during 1996-2008. Feiz Journal. 2013;7:495-500.

12. Korlacki W, Korecka K, Dzielicki J. Foreign body aspiration in children: diagnostic and therapeutic role of bronchoscopy. Pediatr Surg Int. 2011; 27:833-7.

13. Mansour B, Elias N. Foreign Body Aspiration in Children with Focus on the Role of Flexible Bronchoscopy: A 5 Year Experience. Isr Med Assoc J. 2015;17:599-603.

14. Tomaskea M, Gerberb A, Stockera S, Weissb M. Tracheobronchial foreign body aspiration in children - diagnostic value of symptoms and signs. Swiss MED Wkly 2006;136:533-8.

15. Ghafari J, Sahebpour A, Mosavi SA, Safar MJ. Studying condition of pulmonary foreign body aspiration in children referring to Bualisina Hospital, Sari, and its related factors during 20012009. Journal of Mazandaran University of Medical Sciences. 2010;20:17-22.

16. Sarısoy Ö, Liman ŞT, Aydoğan M, Topçu S, Korkmaz B, ve ark. Çocukluk çağı yabancı cisim aspirasyonları: klinik ve radyolojik değerlendirme. Çocuk Sağlığı ve Hastalıkları Dergisi. 2007; 50:96-101.

17. Baram A, Sherzad H, Saeed S, Kakamad FH, Hamawandi AMH. Tracheobronchial Foreign Bodies in Children: The Role of Emergency Rigid Bronchoscopy. Global Pediatric Health. 2017;4:1-6

18. Mallick MS, Khan AR, Al-Bassam A. Late Presentation of Tracheobronchial Foreign Body Aspiration in Children. J Trop Pediatr. 2005;51:145-8.

19. Jose A, Cataneo M, Cataneo DC, Ruiz Jr RL. Management of tracheobronchial foreign body in children. Pediatr Surg Int. 2008;24:151-6.

20. Sirmali $M$, Türüt $H$, Kısacık E, Fındık $G$, Kaya $S$, Tastepe I. The Relationship between Time of Admittance and Complications in Paediatric Tracheobronchial Foreign Body Aspiration. Acta Chir Bel. 2005;105:631-4.

21. Singh $H$, Parakh A. Tracheobronchial foreign body aspiration in children. Clin Pediatr. 2014;53:415-9. 